\author{
Eukasz Myczko $\cdot$ Zuzanna M. Rosin \\ Piotr Skórka $\cdot$ Przemysław Wylegała \\ Marcin Tobolka • Monika Fliszkiewicz \\ Tadeusz Mizera $\cdot$ Piotr Tryjanowski
}

\title{
Effects of management intensity and orchard features on bird communities in winter
}

Received: 26 July 2012/ Accepted: 21 February 2013/Published online: 21 March 2013

(C) The Author(s) 2013. This article is published with open access at Springerlink.com

\begin{abstract}
The knowledge and conservation of diminishing valuable habitats in agricultural landscapes are of key importance in saving declining farmland biodiversity. One of these habitats is the traditional orchard whose role in supporting birds is still poorly known, especially in winter. We counted birds in 106 orchards differing in management intensity (abandoned, traditional, and intensive) during December 2009 and January 2010 in Wielkopolska, western Poland and measured site characteristics and composition of surrounding landscapes for every orchard. Old abandoned and traditionally managed orchards had significantly higher bird species richness than intensive ones. Irrespective of orchard type, bird species richness as well as density were positively influenced by the cover of unmown herb layer in orchards and tree diversity. Tree and fruit densities positively affected bird species richness and density mainly in abandoned orchards while in other orchard types the effect of these variables was less pronounced. Land cover diversity in a landscape had a positive effect on species richness and density mostly in abandoned orchards and we believe that this effect reflects the elevated utilization of such orchards by birds from the surrounding landscape. Thus, abandoned, as
\end{abstract}

Electronic supplementary material The online version of this article (doi:10.1007/s11284-013-1039-8) contains supplementary material, which is available to authorized users.

\footnotetext{
Ł. Myczko · P. Skórka · M. Tobolka · M. Fliszkiewicz

T. Mizera $\cdot$ P. Tryjanowski $(\bowtie)$

Institute of Zoology, Poznań University of Life Sciences,

Wojska Polskiego 71C, 60-625 Poznań, Poland

E-mail: piotr.tryjanowski@gmail.com

Tel.: + 48-618487656

Fax: + 48-618487649

Z. M. Rosin

Department of Cell Biology, Faculty of Biology, Adam Mickiewicz University, Umultowska 89, 61-614 Poznań, Poland

P. Wylegała

Polish Society for Nature Protection Salamandra,

Stolarska 7/3, 60-788 Poznań, Poland
}

well as traditionally managed orchards seems to be especially important habitats that offer food source and refuge for wintering birds and should be protected. We propose to diversify fruit production by planting various tree species, leaving part of the herb layer unmown and several trees unharvested in intensive orchards in order to improve suitability of modern orchards for birds.

Keywords Apple Ecosystem services · Farmland . Fruit $\cdot$ Landscape $\cdot$ Poland

\section{Introduction}

Agricultural intensification and changes in farming practice has led to the fragmentation and loss of seminatural habitats, the disappearance of field margins, as well as midfield woods and hedges and, in effect, the formation of large monoculture crop fields (Meeus 1990; Burel and Baudry 1995; EEA 2010). European farmland biodiversity, in a result, declined (Thomas et al. 2004; Donald et al. 2006). Therefore, conservation and knowledge of diminishing valuable habitats in agricultural landscapes are of key importance for saving endangered farmland biodiversity (Wenzel et al. 2006; Tryjanowski et al. 2011).

Among these habitats, orchards deserve special attention. Old traditional orchards belong to species-rich High Nature Value farming systems in Europe (Cooper et al. 2007). They constitute a refuge for many arthropod and breeding bird species that are attached to woody habitats and do not occur in intensive open agricultural landscapes (Herzog 1998; Bailey et al. 2010). Some specific features of orchards make them of key importance for farmland biodiversity on local, as well as landscape scales. Planting orchards is a long-lasting tradition in temperate areas and they belong to perennial crops, therefore, this is a reason why orchards are regarded as a highly stable, predictable habitat for many organisms (Brown and Welker 1992; Kozár 1992). The multi-strata design of orchards and the presence of adjacent weeds 
and hedges contribute to diversity of arthropods and birds (Rands 1986; Kwiatkowska 1989; Simon et al. 2010). In addition, a high abundance of flowers and fruits constitute an excellent source of food for pollinating insects. On a landscape scale, orchards may contribute to plant diversity in the adjacent agricultural areas and in turn to an increase of breeding and foraging habitats for many animal species in crops (Boller et al. 2004). A century ago, in the agricultural landscapes of central Europe, there were strong traditions of maintenance of small orchards adjacent to households. However, during the last few decades they have been widely abandoned in favor of larger monocultures because of their relatively low economic value (Jermaczek and Jermaczek 2003). In the current European agricultural landscape, orchards are dominated by large, intensively managed orchards aimed at maximizing fruit production. As a consequence, these new orchards are heavily sprayed with insecticides and have very few herbaceous plants or hedges. Studies on avifauna in intensive orchards are limited and authors mainly report on the influence of pesticides on the reproductive rate of passerines (e.g., Bouvier et al. 2005) or, rarely, on bird diversity (Rösler 2003; Genghini et al. 2006; Wiacek and Polak 2008; Bouvier et al. 2011; MacLeod et al. 2012). Moreover, the relative effects of abandonment, traditional management as well as modern intensive management of orchards on bird and other organism communities is poorly recognized (Tryjanowski et al. 2009, 2011). Bird species richness and abundance in orchards may depend not only on the management of the orchard but also on the surrounding landscape composition (Krebs et al. 1999; Benton et al. 2003). However, there are only a few studies on the influence of orchard characteristics and their surroundings on bird communities (Agerberg 2007; Wiacek and Polak 2008; Bailey et al. 2010).

Winter is a critical period for many sedentary bird species because of the marked decline of resources and harsh weather conditions (Brown and Roth 2002; Skórka and Wójcik 2005; Arizaga et al. 2012). In many orchards some fruits are left, so they may constitute a good source of food for birds trying to survive winter in farmland (Skórka et al. 2006). Moreover, these habitats are also hibernation sites for many insect species (Harwood et al. 1992; Lys and Nentwig 1994) that may constitute food resource for birds which consequently contribute to natural pest control (Tryjanowski et al. 2009). Therefore, the presence of diverse bird species in winter may also be beneficial for orchards and adjacent farmland from economical point of view. However, as far as we are aware, there are a lack of studies of birds wintering in different orchard types in central Europe, thus their importance for conservation of birds during winter is not recognized.

In this paper, we investigated how the management of orchards (intensive, extensive, abandoned), characteristics of orchards (e.g., area, density of trees and fruits) and diversity of land cover in a landscape influence bird species richness and density during winter.

\section{Materials and methods}

We selected 106 orchards from the area covering $24,000 \mathrm{~km}^{2}$ located in the Wielkopolska district in western Poland. Poland is the largest apple producer in Europe, and Wielkopolska is one of its leading districts (Bański 2008). Between the middle of December 2009 and the middle of January 2010 one visit was paid to each orchard to survey birds. Birds were surveyed during favorable weather conditions (no snowfall or rainfall, wind below $4 \mathrm{~m} \mathrm{~s}^{-1}$ ) between 8:00 and 14:00. The maximal distance between orchards was $197 \mathrm{~km}$ and minimal $1 \mathrm{~km}$. Orchards were randomly assigned to observers, however they specified how many orchards were able to survey (mean $=5$ orchards per observer, range 1-12 orchards). Observers walked randomly in the orchard. The walks in orchards followed a zig-zag pattern in order to cover the entire area of orchard visually and aurally. Observers walked alone both on the edge and in the interior of orchards. In most of the orchards, it was very easy to encompass the entire area of orchard visually because trees were without leaves. It was also very easy to follow movements of birds in order to not count them twice. The duration of the survey was proportional to the orchard size (Schoereder et al. 2004) with $20 \mathrm{~min}$ spent per 1 ha but no shorter than $10 \mathrm{~min}$ in the smallest orchards.

We considered detectability of birds to be high in our surveys. First, winter in Poland is a period when deciduous trees do not carry leaves. Thus, visibility is high. Secondly, orchards, even the abandoned ones, are structurally very simple habitats. There is usually a very low number of shrubs inside, trees have many branches cut, and trees are planted in rows what makes birds easy to detect there. Thirdly, birds in winter are more mobile and gather in flocks. These flocks often contain different species and this social behavior of birds may lead to their increased detectability. For example, many tits, woodpeckers, and nuthatches form multi-species flocks, which occupy small areas throughout the winter (Alatao 1982; Matthysen 1990). Finally, we also performed analysis on calculated number of species to correct for imperfect detection (for the details see, "Statistical analyses").

We measured the following environmental variables potentially affecting bird species richness (number of species) and density (number of individuals $\mathrm{ha}^{-1}$ ):

1. type of orchard: intensively managed, extensively managed, or abandoned;

2. orchard area (ha);

3. tree density (number of trees $\mathrm{ha}^{-1}$ );

4. tree species diversity index;

5. fruit density (fruits ha ${ }^{-1}$ ). Calculated from both fruits hanging on trees and laying on the ground;

6. cover of unmown herb layer within the orchard (\%);

7. covers $(\%)$ of agricultural fields;

8. grasslands; 
9. forests;

10. orchards;

11. human settlements within a 500-m radius of the orchard boundary. All these land covers types were correlated between each other therefore, we combined them in a land cover diversity index.

The above variables may be assigned to four main groups of factors: orchard management scheme (variable 1), structural complexity of orchards $(2,3,4)$, food resources $(5,6)$, and diversity of surrounding landscape (7). Abandoned orchards were usually located next to abandoned human settlements. Obviously, no specific management was applied in this orchards (no pesticide use, no tree protection from frost, no use of fertilizers). Fruits were collected mostly by occasional visitors. In traditionally managed orchards, fruit production was of low intensity, mostly to fulfill needs of owners. No pesticide use was applied there, but trees were protected from low temperatures, painted with lime to preclude some pests and the herb layer was occasionally cut. Usually, most of the fruits were harvested when ripe. Intensively managed orchards were easily distinguishable as herb layer was usually mown a few times per year, branches were regularly cut and pesticide was applied in high supply during the fruit growth (10-14 sprayings per season). We excluded direct effect of pesticides on birds during winter because the grace period was shorter than time lasting between the last spraying and our winter surveys. However, pesticides may have indirect effect since it may influence the number of hibernating insects in trees. Information on pesticide usage was gathered from interviews with orchard owners.

Environmental variables 2 and $7-11$ were calculated with ImageJ software or directly in the field with the use of a GPS. We used high-resolution images freely available in National Data Base Geoportal (http:// maps.geoportal.gov.pl/webclient/). Variables 1, 3, 5, and 6 were determined during field surveys. All trees were counted in the small- and medium-sized orchards but in the larger ones, the number of trees was estimated by multiplying number of rows with trees and number of trees counted in one row. Tree species in orchards were determined during field surveys and during interviews with owners. We also counted all fruits (mostly apples) left on trees and on the ground in small orchards. In the large orchards, the number of fruits was estimated by random selection of trees located along transects throughout the orchard where fruits (both on trees and under them) were counted and then interpolated for the entire orchard. At least $10 \%$ of all trees had to be surveyed for this purpose. Both tree and fruit densities are presented in number of individuals per hectare. Tree diversity and land cover diversity indices were expressed by Simpson reciprocal diversity index $(1 / D)$ (Simpson 1949). The value of this index has 1 as the lowest possible figure. This figure would represent a composition containing only one tree species or only one land cover type. The higher the value, the greater the fruit tree species diversity or land cover diversity in the surrounding of orchards. In case of land cover diversity, the value of this index was positively correlated with forest cover $\left(r^{2}=0.106, p<0.001\right)$, grassland cover $\left(r^{2}=0.192, p<0.001\right)$, orchard cover $\left(r^{2}=0.206\right.$, $p<0.001)$ and cover of human settlements $\left(r^{2}=\right.$ $0.044, p=0.032$ ) in a $500-\mathrm{m}$ radius from the orchard boundary. The variables describing land cover were strongly correlated between each other and land diversity index allowed to compile them into one variable.

Earlier studies showed that the landscape structure played a role for bird species richness and density (Söderström and Pärt 2000; Herzon and O'Hara 2007) and we choose the radius of $500 \mathrm{~m}$ because it described close proximity of orchards. Management recommendations are much easier to incorporate at such small (local) spatial scale than at larger ones (Mouysset et al. 2011). We also did not count all small landscape features (e.g., singular trees or shrubs) because at the scale of study and in so many orchards it was simply infeasible to collect such data. Moreover, our models (see "Results") generally explained quite large proportion of variation in the species richness and density, thus we probably included most of the meaningful variables.

The basic characteristics of investigated orchards are summarized in Table 1. For correlation coefficients between all continuous environmental variables used in the analyses, see Supplementary material.

\section{Statistical analyses}

We used one-way analysis of variance to compare features of abandoned, traditionally and intensively managed orchards. The stepwise forward regression with selection of variables based on Akaike information criterion (Burnham and Anderson 2002) was used to find those ones that affected species richness and bird density. In models, we introduced all fixed effects and all interactions between orchard type and continuous variables. These interactions tested if species richness and density of birds was differentially affected by the same environmental variables in the three orchard types. $\log 10$ transformation was used to normalize data distributions and to remove the effect of outlying observations (Quinn and Keough 2002) in explanatory and dependent variables. The explanatory continuous variables were standardized to allow direct comparison of their function slopes (betas).

We also performed additional analyses on factors affecting bird species richness and density with generalized linear models (GLM) because dependent variables were count data (Supplementary material). When we used Poisson error variance in GLM we found that the results suffered from the substantial overdispersion, especially when analyzing bird densities (overdispersion parameter $=36$ ). Thus, we analyzed bird densities with 
the GLM with the negative binomial error variance. Basically, GLM with Poisson and binomial error variance distributions produced similar results to that received from stepwise regression and these results are presented in the Supplementary material.

Analysis of variance and stepwise regression and GLM with Poisson and negative binomial error variances was performed in JMP 9 and SPSS 19 software.

Bird surveys often suffer from low detectability of species (Elphick 2008). As we explained above, we did not believe it was a serious problem in our study but we also calculated number of species with different methods that account for imperfect detectability, all implemented in the software Spade (available from: http://chao.stat.nthu. edu.tw/softwareCE.html). The bias-corrected Chao 1 estimate (Shen et al. 2003; Chao 2005; Chao et al. 2006) was chosen because other methods did not calculate number of species from small samples. There was a strong positive correlation between observed and estimated number of species and statistical models based on these two data sets gave similar results (see, Supplementary material for results of the stepwise regression analysis made on estimated number of species and for some cautions on the possible biases when interpreting these results).

Canonical ordination was used to relate the density of the individual bird species to the environmental variables using the CANOCO 4.5 package. Since the length of the longest gradient in DCCA was short (2.01) we used redundancy analysis (RDA) for this ordination. We used forward selection of variables in RDA to find out which variables significantly affected bird species communities in orchards.

\section{Results}

Features discriminating different orchard types

Traditionally managed and abandoned orchards were smaller, had lower tree density and orchard cover in the landscape than intensive ones (Table 1). Traditionally managed and abandoned orchards also had greater unmown cover of the herb layer, higher cover of human settlement and generally higher land cover diversity in the landscape than intensively managed orchards (Table 1).

Factors affecting bird species richness

In total, 39 bird species and 2,325 individuals were noted in all orchards (Table 2). Species richness was highest in abandoned orchards and lowest in intensive ones (Table 3; Fig. 1). Independently of orchard type, species richness was positively related to orchard area (beta $=$ $1.099 \pm 0.305)$, the unmown cover of the herb layer (beta $=0.826 \pm 0.317$ ), tree density (beta $=0.550 \pm$ 0.245 ), tree diversity (beta $=0.583 \pm 0.253$ ), and land cover diversity (beta $=0.076 \pm 0.028)$ (Table 3 ).

Factors affecting density of birds

We did not find statistically significant differences in density of birds between three orchard types during

Table 1 Basic characteristics (mean \pm SE) of orchards and their landscapes by orchard type

\begin{tabular}{|c|c|c|c|c|}
\hline \multirow[t]{2}{*}{ Variable code } & \multicolumn{3}{|l|}{ Orchard type } & \multirow[t]{2}{*}{ ANOVA test and $p$ value* } \\
\hline & $\begin{array}{l}\text { Abandoned (A) } \\
n=38\end{array}$ & $\begin{array}{l}\text { Extensive (B) } \\
n=45\end{array}$ & $\begin{array}{l}\text { Intensive (C) } \\
n=23\end{array}$ & \\
\hline Area & $0.47 \pm 0.05$ & $0.42 .0 \pm 0.06$ & $2.85 \pm 0.36$ & $\begin{array}{l}F_{(2,103)}=21.59 ;<0.001 \\
C>A \text { and } B\end{array}$ \\
\hline TreeDen & $201.8 \pm 26.1$ & $270.5 \pm 37.6$ & $824.6 \pm 100.1$ & $\begin{array}{l}F_{(2,103)}=9.90 ;<0.001 \\
C>A \text { and } B\end{array}$ \\
\hline TreeDiv & $1.7 \pm 0.1$ & $1.6 \pm 0.1$ & $1.6 \pm 0.1$ & $F_{(2,103)}=0.03 ; 0.970$ \\
\hline NotMown & $90.7 \pm 2.0$ & $55.9 \pm 4.2$ & $28.5 \pm 3.5$ & $\begin{array}{l}F_{(2,103)}=24.17 ;<0.001 \\
A>B>C\end{array}$ \\
\hline FruitDen & $1,234.5 \pm 405.3$ & $1,350.6 \pm 372.4$ & $525.7 \pm 530.2$ & $F_{(2,103)}=0.869 ; 0.422$ \\
\hline AppleTree & $66.2 \pm 5.8$ & $64.7 \pm 4.9$ & $51.9 \pm 10.1$ & $F_{(2,103)}=0.17 ; 0.314$ \\
\hline OrchCov & $3.8 \pm 0.9$ & $3.4 \pm 0.9$ & $13.3 \pm 1.3$ & $\begin{array}{l}F_{(2,103)}=11.73 ;<0.001 \\
\mathrm{C}>\mathrm{A} \text { and } \mathrm{B}\end{array}$ \\
\hline GrassCov & $9.7 \pm 2.2$ & $4.9 \pm 1.0$ & $10.2 \pm 1.4$ & $F_{(2,103)}=1.59 ; 0.207$ \\
\hline ForCov & $13.1 \pm 2.1$ & $12.3 \pm 2.2$ & $8.9 \pm 1.0$ & $F_{(2,103)}=0.14 ; 0.869$ \\
\hline Build & $21.2 \pm 2.3$ & $25.9 \pm 2.3$ & $9.3 \pm 1.2$ & $\begin{array}{l}F_{(2,103)}=4.49 ; 0.013 \\
A \text { and } B>C\end{array}$ \\
\hline LandDiv & $2.29 \pm 0.15$ & $1.88 \pm 0.11$ & $1.85 \pm 0.12$ & $\begin{array}{l}F_{(2,103)}=3.090 ; 0.050 \\
A>B \text { and } C\end{array}$ \\
\hline
\end{tabular}

Results in bold are statistically significant $(p<0.05)$

Area orchard area (ha), TreeDen tree density (number of trees/ha), TreeDiv tree diversity index, NotMown percentage cover of orchard herb layer that was unmown, FruitDen density of fruits/ha; AppleTree percentage share of apple trees in orchards, OrchCov percentage cover of orchard within $500 \mathrm{~m}$ from the orchard, GrassCov percentage cover of grassland within $500 \mathrm{~m}$, ForCov percentage cover of forest within $500 \mathrm{~m}$, Build percentage cover of buildings within $500 \mathrm{~m}$, LandDiv land cover diversity index

* Significant differences in post hoc Tukey test 
Table 2 List of bird species and their abundance in surveyed orchards

\begin{tabular}{|c|c|c|c|c|c|}
\hline No. & Species & $\begin{array}{l}\text { Abandoned } \\
n=38\end{array}$ & $\begin{array}{l}\text { Extensive } \\
n=45\end{array}$ & $\begin{array}{l}\text { Intensive } \\
n=23\end{array}$ & $\begin{array}{l}\text { Total } \\
n=106\end{array}$ \\
\hline 1 & Fieldfare Turdus pilaris & 74 & 222 & 326 & 622 \\
\hline 2 & Tree Sparrow Passer montanus & 147 & 229 & 124 & 500 \\
\hline 3 & Great Tit Parus major & 133 & 145 & 21 & 299 \\
\hline 4 & Yellowhammer Emberiza citrinella & 33 & 135 & 88 & 256 \\
\hline 5 & European Greenfinch Carduelis chloris & 26 & 46 & 71 & 143 \\
\hline 6 & Blackbird Turdus merula & 58 & 19 & 26 & 103 \\
\hline 7 & Blue Tit Cyanistes caeruleus & 41 & 31 & 4 & 76 \\
\hline 8 & Chaffinch Fringilla coelebs & 6 & 1 & 46 & 53 \\
\hline 9 & House Sparrow Passer domesticus & 17 & 36 & 0 & 53 \\
\hline 10 & Hawfinch Coccothraustes coccothraustes & 10 & 5 & 7 & 22 \\
\hline 11 & Eurasian Collared Dove Streptopelia decaocto & 5 & 17 & 0 & 22 \\
\hline 12 & Eurasian Siskin Carduelis spinus & 0 & 20 & 0 & 20 \\
\hline 13 & Corn Bunting Emberiza calandra & 5 & 14 & 0 & 19 \\
\hline 14 & Long-tailed Tit Aegithalos caudatus & 18 & 0 & 0 & 18 \\
\hline 15 & Brambling Fringilla montifringilla & 8 & 4 & 6 & 18 \\
\hline 16 & Eurasian Jay Garrulus glandarius & 9 & 4 & 1 & 14 \\
\hline 17 & Magpie Pica pica & 8 & 5 & 1 & 14 \\
\hline 18 & Marsh Tit Poecile palustris & 9 & 4 & 0 & 13 \\
\hline 19 & Linnet Carduelis cannabina & 11 & 0 & 0 & 11 \\
\hline 20 & Redpoll Carduelis flammea & 0 & 3 & 7 & 10 \\
\hline 21 & Mistle Thrush Turdus viscivorus & 3 & 6 & 0 & 9 \\
\hline 22 & Great-spotted Woodpecker Dendrocopos major & 5 & 3 & 0 & 8 \\
\hline 23 & Goldfinch Carduelis carduelis & 2 & 0 & 5 & 7 \\
\hline 24 & Reed Bunting Emberiza schoeniclus & 0 & 5 & 2 & 7 \\
\hline 25 & Eurasian Bullfinch Pyrrhula pyrrhula & 2 & 5 & 0 & 7 \\
\hline 26 & Pheasant Phasianus colchicus & 1 & 0 & 5 & 6 \\
\hline 27 & Willow Tit Poecile montanus & 5 & 0 & 0 & 5 \\
\hline 28 & Common Buzzard Buteo buteo & 0 & 2 & 2 & 4 \\
\hline 29 & Eurasian Nuthatch Sitta europea & 2 & 2 & 0 & 4 \\
\hline 30 & Crested Tit Lophophanes cristatus & 3 & 0 & 0 & 3 \\
\hline 31 & Sparrowhawk Accipiter nisus & 1 & 1 & 0 & 2 \\
\hline 32 & Rough-legged Buzzard Buteo lagopus & 0 & 0 & 2 & 2 \\
\hline 33 & Carrion Crow Corvus corone & 2 & 0 & 0 & 2 \\
\hline 34 & Middle Spotted Woodpecker Dendrocopos medius & 2 & 0 & 0 & 2 \\
\hline 35 & Robin Erithacus rubecula & 1 & 1 & 0 & 2 \\
\hline 36 & Goshawk Accipiter gentilis & 0 & 0 & 1 & 1 \\
\hline 37 & Green Woodpecker Picus viridis & 0 & 1 & 0 & 1 \\
\hline 38 & Starling Sturnus vulgaris & 0 & 0 & 1 & 1 \\
\hline 39 & Eurasian Wren Troglodytes troglodytes & 1 & 0 & 0 & 1 \\
\hline
\end{tabular}

Table 3 Final general linear models testing effects of orchard characteristics on bird species richness and density

\begin{tabular}{|c|c|c|c|c|c|c|}
\hline \multirow[t]{2}{*}{ Variable code } & \multicolumn{3}{|c|}{ Species richness } & \multicolumn{3}{|c|}{ Density } \\
\hline & $d f$ & $F$ & $p$ & $d f$ & $F$ & $p$ \\
\hline OrchType & 2 & 3.347 & 0.039 & 2 & 2.108 & 0.127 \\
\hline Area & 1 & 12.994 & $<0.001$ & 1 & 35.200 & $<0.001$ \\
\hline NotMown & 1 & 6.784 & 0.011 & 1 & 7.756 & 0.006 \\
\hline FruitDen & 1 & - & - & 1 & 4.699 & 0.033 \\
\hline TreeDen & 1 & 4.837 & $\mathbf{0 . 0 3 0}$ & - & - & - \\
\hline TreeDiv & 1 & 5.275 & 0.024 & - & - & - \\
\hline LandDiv & 1 & 12.212 & $<0.001$ & 1 & 34.808 & 0.031 \\
\hline Area $\times$ OrchType & 2 & 2.001 & 0.112 & - & - & - \\
\hline TreeDens $\times$ OrchType & - & - & - & 2 & 8.99 & 0.011 \\
\hline LandDiv $\times$ OrchType & 2 & 2.592 & 0.071 & 2 & 3.101 & 0.050 \\
\hline FruitDen $\times$ OrchType & - & - & - & 2 & 3.297 & 0.041 \\
\hline
\end{tabular}

Result of the forward stepwise procedure based on the Akaike criterion. Significant effects are emboldened. Model for species richness explained $35 \%$ of variation and model for density explained $45 \%$ of variation. For explanations of the variable codes, see Table 1. Results in bold are statistically significant $(p<0.05)$

winter (Table 3; Fig. 1). Independently of the orchard type, bird density was positively related to unmown cover of herb layer (beta $=0.444 \pm 0.159$ ) but negatively by orchard size (beta $=-0.947 \pm 0.160$; Table 3). There were significant interactions between orchard type and tree density, land cover diversity in the 

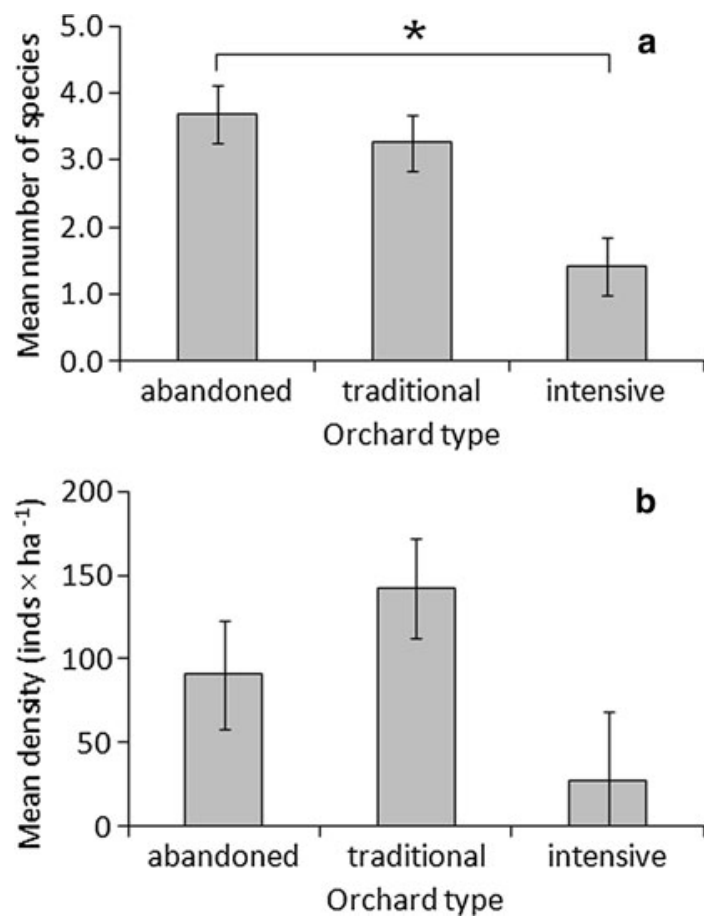

Fig. 1 Species richness (a) and density (b) of birds wintering in orchards of different types. Means with standard errors are presented. ${ }^{*} p<0.050$

surrounding landscape, and fruit density (Table 3). The relationship between tree and bird densities was strong and positive in abandoned orchards (beta $=0.648 \pm$ $0.312, p=0.048$ ), weaker and nonsignificant for traditionally managed orchards (beta $=0.226 \pm 0.206$, $p=0.533$, n.s.), and a negative relationship in intensively managed ones $($ beta $=-0.650 \pm 0.370, \quad p=0.102$, n.s.). The relationship between land cover diversity and bird density was the strongest and positive for abandoned orchards (beta $=0.659 \pm 0.265, p=0.015$ ), weaker and nonsignificant for intensive orchards (beta $=0.524$ $\pm 0.308, p=0.092$ ) but slightly negative for traditionally managed orchards (beta $=-0.248 \pm 0.265$, $p=0.352$ ). Similarly, the relationship between fruit and bird densities was strong and positive in abandoned orchards (beta $=0.514 \pm 0.256, p=0.048$ ), attenuated in intensively managed ones (beta $=0.423 \pm 0.382$, $p=0.271$ ), and the relationship was slightly negative in traditionally managed orchards (beta $=-0.096 \pm$ $0.247, p=0.698)$.

Species response to environmental variables

First and second canonical axes of the RDA explained $22 \%$ of the variation in species composition in the studied orchards, of which $83 \%$ was explained by environmental factors (Fig. 2). Forward selection of environmental variables showed that tree density, tree diversity, orchard area, and abandoned orchards had

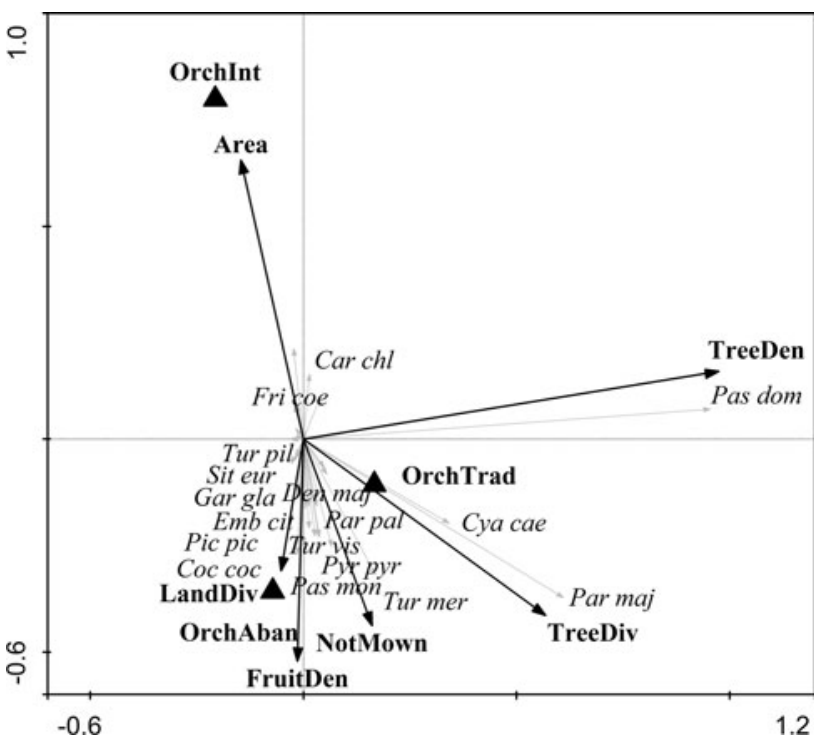

Fig. 2 RDA ordination of the species in relation to environmental variables in the studied orchards. Species are identified by abbreviated scientific names presented in Table 1. Species occurring in less than five orchards have been omitted. OrchIn intensively managed orchard. For explanation of other variable codes see Tables 1 and 2

Table 4 Results of forward selection analysis of environmental variables in RDA, explaining patterns in bird community structure in the orchards during winter

\begin{tabular}{lrl}
\hline Variable code & \multicolumn{1}{l}{$l$} & $p$ \\
\hline TreeDen & $\mathbf{2 3 . 3 4}$ & $\mathbf{0 . 0 0 2}$ \\
TreeDiv & $\mathbf{2 . 4 4}$ & $\mathbf{0 . 0 0 4}$ \\
Area & $\mathbf{1 . 6 2}$ & $\mathbf{0 . 0 3 0}$ \\
OrchAban & $\mathbf{1 . 4 0}$ & $\mathbf{0 . 0 4 8}$ \\
FruitDen & 1.30 & 0.102 \\
LandDiv & 1.38 & 0.086 \\
NotMown & 1.05 & 0.396 \\
OrchTrad & 0.88 & 0.618
\end{tabular}

The analysis was performed using Monte Carlo tests with 499 permutations. Variables are ordered according to their stepwise inclusion into the model. Statistically significant effects are in bold $(p<0.05)$. For further explanation, see Table 1

OrchAban abandoned orchards, OrchTrad orchard traditionally managed

significant effects on the composition of bird communities (Table 4). Tree diversity positively affected Great Tit Parus major and Blue Tit Cyanites caeruleus. Tree density positively affected densities of House Sparrow Passer domesticus. Cover of unmown vegetation, fruit density within orchards and diversity of surrounding habitats positively affected several seed-eating species such as Tree Sparrow Passer montanus and Yellowhammer Emberiza citrinella, and many other species that are usually omnivorous during winter (like Blackbird Turdus merula, Fieldfare T. pilaris, Mistle Thrush T. viscivorus, Eurasian Nuthatch Sitta europea, Great-spotted Woodpecker Dendrocopos major; Fig. 2). Densities of most species were lower in large intensive orchards (Fig. 2). 


\section{Discussion}

Our study revealed that the type of orchard management had an important impact on wintering bird communities and abandoned orchards had significantly higher bird species richness than intensive ones. Furthermore, our study underlines the importance of various orchard characteristics such as area, cover of unmown herb layer, tree diversity and density, as well as the diversity of the surrounding landscape for species richness and density of birds wintering in orchards.

The importance of orchards for birds, mostly during the breeding season, has already been identified (e.g., Bouvier et al. 2005; Wiacek and Polak 2008). It was shown that orchards constitute a breeding habitat for many farmland bird species linked with small mid-field woods (e.g., Chaffinch, Fieldfare, Hawfinch) (Kwiatkowska 1989; Wiacek and Polak 2008). Our results indicate the same stay true also for wintering species. To the best of our knowledge, there is a lack of studies on birds wintering in orchards in central Europe. In western Europe, Rey (2011) showed that olive orchards in Spain maintain high densities of frugivorous birds during winter. However, winter climatic conditions are substantially different in the Iberian Peninsula from that noted in central Europe. Studies in North America indicated the importance of the abundance of fruit trees for some wintering and migrating frugivorous bird species (Kwit et al. 2004; Foster 2007). Our study suggests that orchards may be important for many other bird groups such as seed-eating passerines and insectivores. Considering the strong decline of many common farmland birds in Europe (Donald et al. 2006) orchards may be one of the key habitats providing refuges, food resources, and, eventually, may improve winter survival of some species (Skórka et al. 2006; Tryjanowski et al. 2011).

Effect of the orchard management on wintering birds

The differences between orchard types illustrate changes in management that took place through recent decades in central Europe (Bański 2008). In our study area, the intensive orchards were larger, had higher tree density, a lower cover of unmown herb layer, a higher cover of orchards, and lower cover of human settlements in their landscapes than traditional ones. These results illustrate current and common in Europe process of farmland management intensification: planting large, one-age, dense monocultures that are often poor in food sources during winter and with a low diversity of surrounding habitats (Geiger et al. 2010). The negative impact of such intensive management of orchards is probably magnified by pesticide usage as was shown for breeding birds (e.g., Bishop et al. 1998; Gill et al. 2000; Wiacek and Polak 2008). In contrast, abandoned orchards had the highest avian species richness as well as significant associations with several species. Old abandoned orchards have probably a more complicated vertical and spatial structure than the other orchard types as well as a high cover of unmown herbs that constitute an excellent food source for birds. The cover of buildings, which strongly correlated with land cover diversity, often traditional homesteads, also probably contributed to the number of bird species in abandoned and extensive orchards since several synanthropic species such as Magpie, House Sparrow, and Collared Dove were observed in orchards.

\section{Effects of orchard size and structural complexity}

Our results indicate that several orchard features have a crucial impact on bird species. Orchard area positively affected species richness and this result is consistent with basic assumptions of species-area relationship (Rosenzweig 1995) as well as results of empirical studies on bird communities living in wooded habitat islands (e.g., Hinsley et al. 1996; Ney-Niffle and Mangel 2000). However, the density of birds showed an inverse relationship with orchard size. This may be related to distribution of resources within orchards (Helzer and Jelinski 1999). Many of the birds recorded in orchards are so-called ecotonal species, which utilize resources in arable fields, grassland patches, mid-field woods, and orchards (Tryjanowski et al. 2009).

Tree density positively affected bird species richness in all orchard types. On the other hand, tree density positively affected bird densities only in abandoned and traditionally managed orchards but negatively in intensive ones. Trees in abandoned orchards are often old, left uncut, and posses dead branches. All of these features may increase bird densities because of rich food resources and also due to many holes that may provide roosting sites. Thus, tree quality (from a bird's perspective) may be high in abandoned orchards and this may explain why densities of birds in abandoned orchards increased with tree density but not in intensively managed orchards where tree density is already extremely high. However, each tree within an orchard is a potential food resource or shelter for birds and adds to the structural complexity of an orchard, and this may explain the positive effect of this variable on species richness, independent of orchard management type. Tree density also significantly affected species composition in orchards as evidenced by redundancy analysis. Some passerine species (for example House Sparrow) may favor densely growing trees because they provide shelter from adverse weather conditions and possibly from birds of prey.

Tree species diversity positively affected bird species richness in all orchards. One of several niche theories argues that species composition is driven by environmental heterogeneity (Bolliger et al. 2002; Tokeshi and Schmid 2002). Thus, a higher number of tree species in an orchard may represent more microhabitats for different species. Birds searching for food depart significantly from random in their use of tree species, even when these trees 
are generally similar in life form (Holmes and Robinson 1981; Unno 2002). Thus, maintaining diverse tree species may significantly contribute to bird species richness in orchards. For example, planting one new tree in an orchard would result in one new bird species there (number of bird species $=0.978 \times$ number of tree species $\left.+1.921, r^{2}=0.260\right)$. This is also confirmed by redundancy analysis, which showed that this variable seemed to be much more important for shaping bird species composition than fruit density, which is usually attributable to orchards and birds.

\section{Food-resource abundance}

Food resources for birds in orchards during winter constitute mainly fruits (both on trees and on the ground), insects hibernating in trees, and seeds of herbs. Fruit density influenced positively the density of birds but not species richness. Fruits, which in our orchards were almost exclusively apples, constitute the main food for Fieldfares, Blackbirds, and Mistle Thrush, have been shown to be one of the prime factors affecting frugivorous bird abundance during winter and migration (Kwit et al. 2004; Skórka et al. 2006; Foster 2007). Fieldfares and Mistle Thrushes often set winter territories when fruits are abundant and chase all other species that try to eat fruit within their territories or even when enter them (Snow and Snow 1984; Skórka et al. 2006). Such winter territories usually encompass several trees with the largest number of fruits. However, in our study, density of Fieldfares was positively related to number of other bird species $[\log 10$ (number of species) $=1.966 \times \log 10$ (density of fieldfares) $\left.+0.825, r^{2}=0.402\right]$. Thus, it is possible that environmental variables played a more important role in shaping species richness that interspecific interactions between birds.

Regardless of the orchard type, avian species richness and density was positively related to the cover of unmown herb layer. The importance of a herb layer rich in seeds for wintering birds is regarded as the factor limiting the occurrence of birds in farmland (e.g., Perkins et al. 2000; Siriwardena and Stevens 2004; Buckingham et al. 2011). Herbs provide food resources for seed-eating birds but they may also benefit arthropods and, in turn, densities of some insectivorous birds. In an open agricultural landscape, seed sources may be hardly available, especially during long periods with thick snow cover. Orchards, on the other hand, act like a shield protecting from wind, and tree canopies may prevent formation of thick snow making weeds and seeds more accessible for birds (author's unpublished observations).

\section{Diversity of surrounding landscape}

Land cover diversity in the landscape positively affected the number of bird species and their density, and these results are in agreement with the hypothesis that spatial heterogeneity may increase species richness and biodiversity in general (e.g., Ricklefs and Lovette 1999; Atauri and De Lucio 2001). Land cover diversity index positively correlated with grassland, forest, orchard and building covers and, therefore, it described their joint effect on birds. Agricultural landscapes that are more diverse are inhabited by more species (Tworek 2004; Herzon and O'Hara 2007; Chiron et al. 2010; Geiger et al. 2010). Such landscapes are also more permeable for moving birds, thus, higher landcover diversity may enhance orchard utilization by birds by reducing effects of orchard isolation. Orchard isolation was found to be the prime factor limiting bird species richness during the breeding season (Bailey et al. 2010). Wiacek and Polak (2008) also found that a higher number of avian species breed in orchards located in landscapes diversified by grasslands, woodlands, and orchards.

\section{Management recommendations and final remarks}

Our study suggests that orchards may be important habitats offering food resources and refuge for several wintering birds. Old abandoned as well as extensively managed orchards are especially valuable habitats and should be protected since their existence is threatened due to agriculture intensification (Cooper et al. 2007). Abandoned and traditionally managed orchards should be included into existing agri-environment schemes to increase ecosystem services in farmland. Moreover, factors that shaped bird community structure in orchards can serve as the basis for recommendations for orchard managers and conservationists. Firstly, we propose to leave part of the herb layer unmown and not harvest several trees in intensive orchards. Birds attracted by these food sources can serve as pest control during the breeding season (Mols and Visser 2002) as well as in winter. Secondly, the management of landscapes around the orchards, e.g., keeping and creation of grassland and forest patches, may benefit conservation of farmland birds and enhance positive role of orchards in agricultural landscapes. The positive effects of landcover diversity suggest that abandoned orchards together with diverse surroundings should constitute a unit of special conservation interest.

Acknowledgments We are grateful to A. Batycki, A. Kasprzak, A. Pikuła, A. Krajewska, R. Bialik, D.K. Cierplikowscy, M. Halsz, H. Frański, J. Mogilnicki, J. Mikołajczyk, J. Lewandowski, K.M. Południewscy, M. Sobolewski, M. Urbańska, N. Dąbrowska, P. Derengowska, R. Hybsz, T. Piasek, and M. Tybiszewski for their help in collecting field data. We also thank T.H. Sparks for his constructive comments on the manuscript and linguistic corrections. Z.M. Rosin was supported by the Adam Mickiewicz University (AMU) Foundation in Poznań scholarship in 2012.

Open Access This article is distributed under the terms of the Creative Commons Attribution License which permits any use, distribution, and reproduction in any medium, provided the original author(s) and the source are credited. 


\section{References}

Agerberg J (2007) Impact des pratiques agricoles et du paysage sur l'avifaune des vergers de pommiers du Sud-Est de la France, Mémoire INRA Avignon-AgroParisTec, p 57

Alatao RV (1982) Effects of temperature on foraging behaviour of small forest birds wintering in northern Finland. Ornis Fenn 59:1-12

Atauri JA, De Lucio JV (2001) The role of landscape structure in species richness distribution of birds, amphibians, reptiles and lepidopterans in Mediterranean landscapes. Land Ecol 16:147-159

Bailey D, Schmidt-Entling MH, Eberhart P, Herrmann JD, Hofer G, Kormann U, Herzog F (2010) Effects of habitat amount and isolation on biodiversity in fragmented traditional orchards. J Appl Ecol 47:1003-1013

Arizaga J, Díez E, Aranguren I, Asenjo I, Cuadrado JF, Elosegi Z, Goikoetxea J, Herrero A, Jauregi JI, Mendiburu A, Sánchez JM (2012) Wintering survival of insect-eating passerines in southern Europe. Bird Study 59:37-42

Bański J (2008) Agriculture of central Europe in the period of economic transformation. In: Bański J, Bednarek M (eds) Contemporary changes of agriculture in east-central Europe. Rural Studies, vol 15. pp 9-22

Benton TG, Vickery JA, Wilson JD (2003) Farmland biodiversity: is habitat heterogeneity the key? Trends Ecol Evol 18:182-188

Bishop CA, Van Der Kraak GJ, Ng P, Smits JEG, Hontela A (1998) Health of tree swallows (Tachycineta bicolor) nesting in pesticide-sprayed apple orchards in Ontario, Canada. II. Sez and thyroid hormone concentrations and testes development. J Toxicol Environ Health 55:561-581

Boller EF, Häni F, Poehling HM (2004) Ecological infrastructures: idea book on functional biodiversity at the farm level. Landwirtschaftliche Beratungszentrale Lindau, Lindau, Suisse

Bolliger J, Kienast F, Bugmann H (2002) Comparing classical community models: theoretical consequences for patterns of diversity. Am Nat 159:1-23

Bouvier J, Ricci B, Agerberg J, Lavigne C (2011) Apple orchard pest control strategies affect bird communities in southeastern France. Environ Toxicol Chem 30:212-219

Bouvier JC, Toubon JF, Boivin T, Sauphanor B (2005) Effects of apple orchard management strategies on the great tit (Parus major) in southeastern France. Environ Toxicol Chem 24:2846-2852

Brown MW, Welker WV (1992) Development of the phytophagous arthropod community on apple as affected by orchard management. Environ Entomol 31:485-492

Brown WP, Roth RR (2002) Temporal patterns of fitness and survival in the Wood Thrush. Ecology 83:958-969

Buckingham DL, Bentley S, Dodd S, Peach WJ (2011) Seeded ryegrass swards allow granivorous birds to winter in agriculturally improved grassland landscapes. Agric Ecosyst Environ 142:256-265

Burel F, Baudry J (1995) Species biodiversity in changing agricultural landscapes: a case study in the Pays d'Auge, France. Agric Ecosyst Environ 55:193-200

Burnham KP, Anderson DR (2002) Model selection and multimodel interference: a practical information-theoretic approach. Springer, Berlin Heidelberg New York

Chao A (2005) Species estimation and applications. In: Balakrishnan N, Read CB, Vidakovic B (eds) Encyclopedia of statistical sciences, 2nd edn, vol 12. Wiley, New York, pp 7907-7916

Chao A, Shen T-J, Hwang WH (2006) Application of Laplace's boundary-mode approximations to estimate species and shared species richness. Aust N Z J Stat 48:117-128

Chiron F, Filippi-Codaccioni O, Jiguet F, Devictor V (2010) Effects of non-cropped landscape diversity on spatial dynamics of farmland birds in intensive farming systems. Biol Conserv 143:2609-2616
Cooper T, Arblaster K, Baldock D, Farmer M, Beaufoy G, Jones G, Poux X, McCracken D, Bignal E, Elbersen B, Washer D, Angelstam P, Roberge JM, Pointereau P, Seffer J, Galvanek D (2007) Final report for the study on HNV indicators for evaluation. Institute for European Environmental Policy, London, p 35

Donald PE, Sanderson FJ, Burfield IJ, van Bommel FPJ (2006) Further evidence of continent-wide impacts of agricultural intensification on European farmland birds, 1990-2000. Agric Ecosyst Environ 116:189-196

EEA (2010) 10 messages for 2010-agricultural ecosystems. European Environment Agency, European Union

Elphick CS (2008) How you count counts: the importance of methods research in applied ecology. J Appl Ecol 45:1313-1320

Foster MS (2007) The potential of fruit trees to enhance converted habitats for migrating birds in southern Mexico. Bird Conserv Intern 17:45-61

Geiger F, de Snoo GR, Berendse F, Guerrero I, Morales MB, Oñate JJ, Eggers S, Pärt T, Bommarco R, Bengtsson J, Clement LW, Weisser WW, Olszewski A, Ceryngier P, Hawro V, Inchausti P, Fischer C, Flohre A, Thies C, Tscharntke T (2010) Landscape composition influences farm management effects on farmland birds in winter: a pan-European approach. Agric Ecosyst Environ 139:571-577

Genghini M, Gellini S, Gustin M (2006) Organic and integrated agriculture: the effects on bird communities in orchard farms in northern Italy. Biodivers Conserv 15:3077-3094

Gill H, Wilson LK, Cheng KM, Trudeau S, Elliott JE (2000) Effects of azinphos - methyl on American robins breeding in fruit orchards. Bull Environ Contam Toxicol 65:756-763

Harwood RWJ, Wratten SD, Nowakowski M (1992) The effects of managed fields margin on hoverfly (Diptera: Syrphidae) distribution and within fields abundance. In: Brighton crop protection conference- pest and diseases. Brighton Crop Protection Council, Hampshire, pp 1033-1037

Helzer CJ, Jelinski DE (1999) The relative importance of patch area and perimeter - area ratio to grassland breeding birds. Ecol Appl 9:1448-1458

Herzog F (1998) Streuobst: a traditional agroforestry system as a model for agroforestry development in temperate Europe. Agrofor Syst 42:61-80

Herzon I, O'Hara RB (2007) Effects of landscape complexity on farmland birds in the Baltic States. Agric Ecosyst Environ 118:297-306

Hinsley SA, Bellamy PE, Newton I, Sparks TH (1996) Influences of population size and woodland area on bird species distributions in small woods. Oecologia 105:100-106

Holmes RT, Robinson SK (1981) Tree species preferences of foraging insectivorous birds in a northern hardwoods forest. Oecologia 48:31-35

Jermaczek A, Jermaczek M (2003) Lets' save old orchards. Klub Przyrodników, Swiebodzin (in Polish)

Kozár F (1992) Organization of arthropod communities in agroecosystems. Acta Phytopathol Entomol Hung 27:365-373

Krebs JR, Wilson JD, Bradbury RB, Siriwardena GM (1999) The second silent spring? Nature 400:611-612

Kwiatkowska G (1989) Birds building open nests in multihectare orchards. Roczniki AR w Poznaniu 208:3-20 (In Polish with English summary)

Kwit C, Levey DJ, Greenberg CH, Pearson SF, McCarty JP, Sargent S, Mumme RL (2004) Fruit abundance and local distribution of wintering hermit thrushes (Catharus guttatus) and yellow-lumped warblers (Dendroica coronata) in south Carolina. The Auk 121:46-57

Lys JA, Nentwig W (1994) Improvement of the overwintering sites for Carabidae, Staphylinidae and Araneae by strip-management in cereal fields. Paleobiologia 38:238-242

Ney-Niffle M, Mangel M (2000) Habitat loss and changes in the species-area relationship. Conserv Biol 14:893-898 
MacLeod CJ, Blackwell G, Benge J (2012) Reduced pesticide toxicity and increased woody vegetation cover account for enhanced native bird densities in organic orchards. J Appl Ecol 49:652-660

Matthysen E (1990) Nonbreeding social organization in Parus. Curr Ornithol 7:209-249

Meeus JHA (1990) The transformation of agricultural landscapes in western Europe. Milieu 6:225-236

Mols CMM, Visser M (2002) Great tits can reduce caterpillar damage in apple orchards. J Appl Ecol 39:888-899

Mouysset L, Doyen L, Jiguet F, Allaire G, Leger F (2011) Bioeconomic modeling for a sustainable management of biodiversity in agricultural lands. Ecol Econ 70:617-626

Perkins AJ, Whittingham MJ, Bradbury RB, Wilson JD, Morris AJ, Barnett PR (2000) Habitat characteristics affecting use of lowland agricultural grasslands by birds in winter. Biol Conserv 95:279-294

Quinn GP, Keough MJ (2002) Experimental design and data analysis for biologists. Cambridge University Press, Cambridge

Rands MRW (1986) Effect of hedgerow characteristics on partridge breeding densities. J Appl Ecol 23:479-487

Rey PJ (2011) Preserving frugivorous birds in agri-ecosystems: lessons from Spanish olive orchards. J Appl Ecol 48:228-237

Ricklefs RE, Lovette IJ (1999) The roles of island area per se and habitat diversity in the species-area relationships of four Lesser Antillean faunal groups. J Anim Ecol 68:1142-1160

Rosenzweig ML (1995) Species diversity in space and time. Cambridge University Press, Cambridge

Rösler S (2003) Natur- und Sozialverträglichkeit des Integrierten Obstbaus, PhD thesis. University of Kassel, Germany, $430 \mathrm{pp}$

Schoereder JH, Galbiati C, Ribas CR, Sobrinho TG, Sperber CF, DeSouza O, Lopes-Andrade C (2004) Should we use proportional sampling for species-area studies? J Biogeogr 31:1219-1226

Shen T-J, Chao A, Lin J-F (2003) Predicting the number of new species in further taxonomic sampling. Ecology 84:798-804

Simon S, Bouvier JC, Debras JF, Sauphanor B (2010) Biodiversity and pest management in orchard systems. A review. Agron Sustain Dev 30:139-152

Simpson EH (1949) Measurement of diversity. Nature 163:688

Siriwardena GM, Stevens DK (2004) Effects of habitat in the use of supplementary food by farmland birds in winter. Ibis 146:144-154
Skórka P, Babiarz T, Skórka J, Wójcik JD (2006) Winter territoriality and fruit defence by the fieldfare (Turdus pilaris). J Ornithol 147:371-375

Skórka P, Wójcik JD (2005) Population dynamics and social behavior of mistle thrush Turdus viscivorus during winter. Acta Ornithol 40:35-42

Snow BK, Snow DW (1984) Long-term defence of fruit by mistle thrushes (Turdus viscivorus). Ibis 126:339-349

Söderström B, Pärt T (2000) Influence of landscape scale on farmland birds breeding in semi-natural pastures. Conserv Biol 14:522-533

Thomas JA, Telfer MG, Roy DB, Preston CD, Greenwood JJD, Asher J, Fox R, Clarke RT, Lawton JH (2004) Comparative losses of British butterflies, birds, and plants and the global extinction crisis. Science 303:1879-1881

Tokeshi M, Schmid PE (2002) Niche division and abundance: an evolutionary perspective. Popul Ecol 44:189-200

Tryjanowski P, Kuźniak S, Kujawa K, Jerzak L (2009) Ekologia ptaków krajobrazu rolniczego. Bogucki Wydawnictwo Naukowe, Poznań

Tryjanowski P, Hartel T, Báldi A, Szymański P, Tobolka M, Herzon I, Goławski A, Konvička M, Hromada M, Jerzak L, Kujawa K, Lenda M, Orłowski M, Panek M, Skórka P, Sparks TH, Tworek S, Wuczyński A, żmihorski M (2011) Conservation of farmland birds faces different challenges in western and central-eastern Europe. Acta Ornithol 46:1-12

Tworek S (2004) Factors affecting temporal dynamics of avian assemblages in a heterogeneous landscape. Acta Ornithol 39:155-163

Unno A (2002) Tree species preferences of insectivorous birds in a Japanese deciduous forest: the effect of different foraging techniques and seasonal change of food resources. Ornithol Sci $1: 133-142$

Wenzel M, Schmitt T, Weitzel M, Seitz A (2006) The severe decline of butterflies on western German calcareous grasslands during the last 30 years: a conservation problem. Biol Conserv 128:542-552

Wiacek J, Polak M (2008) Bird community breeding in apple orchards of central Poland in relation to some habitat and management features. Pol J Environ Sci 17:951-956 